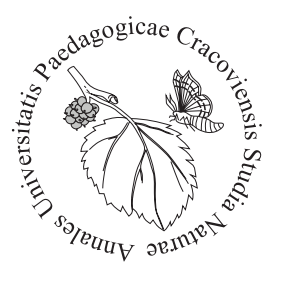

Sylwia Śliwińska-Wilczewska Institute of Oceanography, University of Gdansk, Av. Piłsudskiego 46, 81-378 Gdynia, Poland; ocessl@ug.edu.pl

\title{
Cyanobacteria and cyanometabolites used in the pharmaceutical and medical industry
}

\section{Introduction}

Cyanobacteria from marine and freshwater habitats are known to produce a diverse array of active compounds (cyanometabolites). These include low molecular weight peptides, polysaccharides, fatty acids, phenols and alkaloids (Burja et al., 2001; Mazur-Marzec et al., 2015). Some of them are a threat to human and environmental health. But many of these natural products possess considerable interest due to their potential applications (Berry et al., 2008; Leão et al., 2012; Almeida et al., 2015). It was estimated that out of the 660 new compounds identified in marine bacteria in the years 1997-2008, till 33\% were derived from cyanobacteria (Imhoff et al., 2011). These compounds could be used to obtain commercial algaecides, herbicides, and insecticides. Furthermore, some of these chemical substances demonstrated antifungal, antibacterial, antiviral and even antitumor activity, which could lead to the development of new drugs from them (Berry et al., 2008). Thus, the issue of commercial application of cyanobacteria and their cyanometabolites requires more attention and investigation.

The first discovery of the healing properties of cyanobacteria took place in 1500 B.C. where the Nostoc sp. species was used to treat several forms of cancer (Singh et al., 2011). In recent years, many studies have been conducted on the use of cyanobacteria as a potential source of new biologically active substances e.g., microginine, cyanopeptin, aeruginosine and spumigine (Głowacka et al., 2007). The last two can be used to treat hypertension, cardiovascular diseases, and viral infections. In turn, microginine is used to cure hypertension, and cyanopeptin for asthma and viral infections (Singh et al., 2011). Bouillomides A and B from Lyngbya bouillonii L.Hoff. \& V.Dem. are strong inhibitors of serine protease, elastase, and chymotrypsin (Rubio et al., 2010). Particularly valuable are such compounds that have of antiviral (cyanovirin, scytovirin), antifungal (fischerelin, cryptophycin, calophycin), antibacterial 
(microviridine, muscoride, nostocin A), antitumor (apratoxins A and D, dolastine) and antimalar (ambigol C) nature (Wright et al., 2005; Głowacka et al., 2007). In the years 1981-2002, over 60\% of anti-cancer and anti-infectious drugs were of natural origin. Currently, due to the high costs of introducing new products to the market by the pharmaceutical industry (500-2000 million dollars), the number of new drugs is decreasing. Currently, drugs are becoming less effective because the resistance of pathogens to antibiotics is increasing. Therefore, it is important to explore new biologically active compounds to produce new drugs (Lam, 2007).

The main aim of this study was to present the knowledge on active compounds of cyanobacteria, which may have potential applications in the pharmaceutical and medical industries. This topic is very important but is still not sufficiently understood. For centuries, human diseases have been treated with natural products because these plant-based, natural drugs are much healthier than their chemical counterparts. In this paper, we showed the positive aspects of cyanobacteria cultivation and possibilities of its commercial use. Algae nomenclature was used here according to AlgaeBase (https://www.algaebase.org/) and other microbes from different sources.

\section{Medical and pharmaceutical use of cyanobacteria}

Initial knowledge of the properties of cyanobacteria enabled their application on an industrial, pharmaceutical, and medical scale. They produce many biologically active cyanometabolites which have, among others, anticancer, antifungal, antiviral, anti-inflammatory, and antimalarial properties (Gupta et al., 2013; Fig. 1). Cyanobacteria also contain pigments that can strengthen the immune system, and even reduce the risk of heart disease multiple sclerosis, cataracts, and age-related diseases, as well as prevent cancer. Pigments can be used both as medicines and cosmetics, as well as natural pigments for products including ice cream, sweets, soft drinks, and milk products. Extract from blue pigment, which is phycocyanin, obtained from the species of e.g., Arthrospira sp., is used in eye shadow, lipsticks and eyeliner. Moreover, this pigment inhibits pancreatic lipase and also, depending on the dose, the growth of Ehrlich cancer cells (El-Baky, 2003). Carotenoids, which are antioxidants, are also anti-cancer drugs substances (Sheih et al., 2009). Chlorophyll together with pigments such as phycocyanin and phycoerythrin have a protective effect against UV radiation on the skin, thus delaying the aging process. In addition, cyanobacteria produce polysaccharides that have the ability to stabilise emulsions and suspensions, form gels, etc., and these can be used in the cosmetics industry as ingredients in nutrients, creams and many other similar products, as well as in the pharmaceutical industry as ingredients in medicines (Głowacka et al., 2007; Tab.1). 

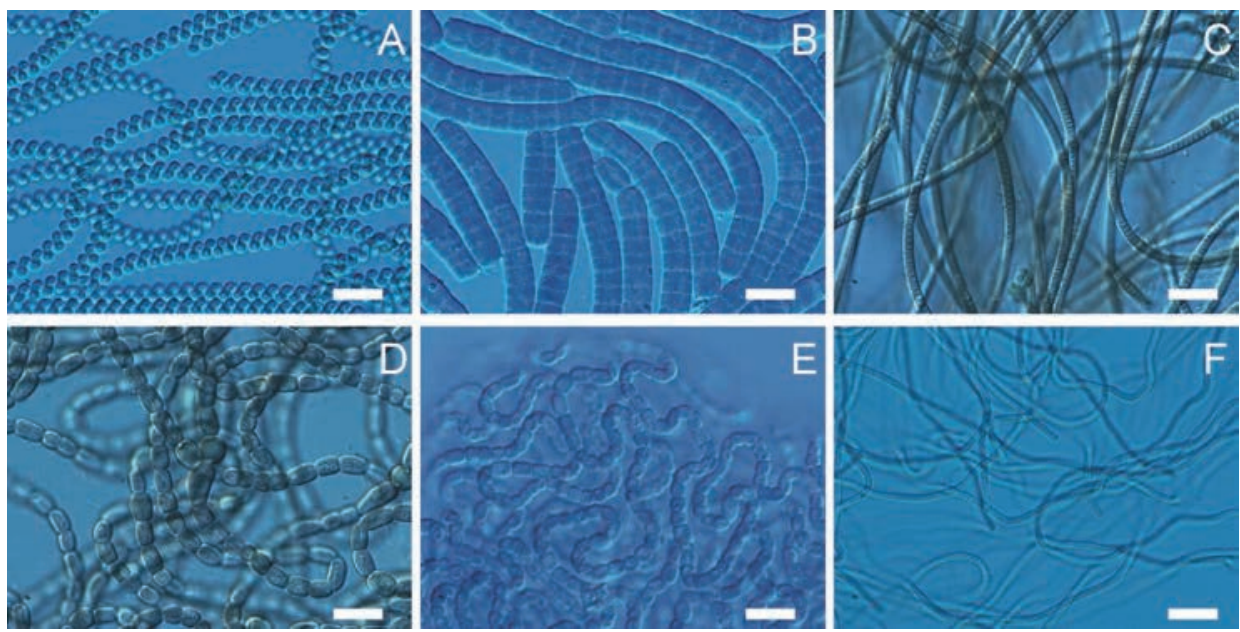

Fig. 1. Examples of cyanobacteria as a potential source for commercial applications: Arthrospira sp. (A), Lyngbya sp. (B), Leptolyngbya sp. (C), Nostoc cf. commune Vauch. ex Born. \& Flah. (D), Nostoc muscorum C.Ag. ex Born. \& Flah. (E), and Pseudanabaena sp. (F). Scale bar $=10 \mu \mathrm{m}$ (Photo. S. ŚliwińskaWilczewska)

\section{Micro- and macroelements from cyanobacteria}

Perhaps, cyanobacteria Arthrospira platensis Gomont can be the richest source of vitamins as well as macro- and microelements. They contain nutrients, i.e. $\beta$-carotene (with antioxidant properties which protect the organism against free radicals), iodine, selenium, zinc, iron, magnesium, manganese, copper and $\gamma$-linolenic acid, derived from the group of omega- 6 fatty acids, glycolipid H-b2, which is an inhibitor of pancreatic lipase and vitamin B12, which is necessary for the proper functioning of nerve tissue, B1, B2, B3 and E (Klasik et al., 2010; Gupta et al., 2013). Isolated compounds of the Arthrospira sp. species have nourishing, strengthening and detoxifying properties, and the extract from its cells has antiallergic, antiviral properties, inhibits carcinogenesis processes, and also reduces blood cholesterol (Głowacka et al., 2007). Arthrospira sp. is also rich in proteins - contain their about 60\% (Ishimi et al., 2006). It also helps alleviate the occurrence of anemia during pregnancy (Nuhu, 2013).

\section{Cyanobacteria compounds with antiviral activity}

Viral diseases, including HIV, affects many people around the world. According to WHO and UNAIDS, 36.7 million people lived with HIV at the end of 2016, of which 1 million died due to it. Thousands of marine organisms, including cyanobacteria, have been tested for antiviral properties (Yasuhara-Bell, Lu, 2010). Such an antiviral compound is cyanovirin produced by Nostoc ellipsosporum Rabenh. ex Born. \& Flah. 
This protein inhibits proliferation of HIV-1, HIV-2, acquired immunodeficiency virus FIV cats and SIV monkeys (Głowacka et al., 2007). Nostoflan polysaccharide from $N$. flagelliforme (Born. \& Flah.) Elen. also has activity against the herpes-1 virus (Singh et al., 2011). Scytovirin isolated from the aqueous extract of Scytonema varium Kütz. ex Born. \& Flah. is also an antiviral protein. It acts similarly to the already mentioned cyanovirin, because both inhibit the process of virus absorption on the surface of host cells. It has been proven that if scitovirin is given up to 8 hours after infection with the virus, it successively prevents the development of infection (Bokesch et al., 2003). In 2002, water extracts from Arthrospira maxima Setchell \& N.L.Gardner cells were tested and they were shown to inhibit the development of infections caused by the HSV-2 and HSV-1 herpes virus, CMV cytomegalovirus and the virus causing Aujeszky's PRV disease. Polysaccharides produced by cyanobacteria including A. platensis, demonstrated the ability to inhibit the replication of HSV, HIV-1, HIV-3, influenza A, and mumps virus, which were cultured in suspensions of human cell cultures (Głowacka et al., 2007). Zainuddin et al. (2002) researched the aqueous and methanolic extract from cyanobacterial cultures of the genus Calothrix, Microcystis, Nodularia, Oscillatoria, Lyngbya and Scytonema to check their activity against influenza A virus in a dog's kidney cells. The most effective extract turned out to be obtained from cyanobacteria of the genus Microcystis. A reduction of approximately $90 \%$ in viral replication was observed due to protease inhibiting activity. None of the methanol extracts was cytotoxic. Besides, Lau et al. (1993) tested the ability of aqueous cyanobacterial extracts to inhibit reverse transcriptase RT of the avian myeloblastoma virus AMV and HIV and it was proved that $18(2.0 \%)$ extracts showed this possibility in the range of over $50 \%$. On this basis, it was concluded that cyanobacteria can be a promising source of compounds used for viral therapies.

\section{Cyanobacteria compounds with antibacterial activity}

Kreitlow et al. (1999) studied hydrophilic and lipophilic extracts of cyanobacteria for their antibacterial activity. In the case of Gram (-) bacteria, no inhibitory activity was found. While for Gram (+) seven species of cyanobacteria from twelve (Anabaena lemmermannii P.G.Richt., A. solitaria Kleb., Limnothrix sp., Microcystis ichthyoblabe (G.Kun.) Kütz., Nodularia sp., Oscillatoria rubescens DC ex Gomont, O. tenuis C.Ag. ex Gomont) showed high activity against at least one of the bacteria such as: Bacillus subtilis Ehren., Micrococcus flavus Cohn and Staphylococcus aureus F.J. Rosenbach. In terms of antibacterial activity, Oufdou et al. (2001) tested the benthic species of cyanobacteria Pseudanabaena sp. and they showed that the extracts secreted by these organisms inhibited the growth of bacteria Escherichia coli T. Esch., Salmonella sp. and Staphylococcus aureus. In turn, antibacterial activity against Bacillus cereus Frank. \& 
Frank., Escherichia coli and Staphylococcus epidermidis Evans have a compound called noscomin obtained from Nostoc commune Vauch. ex Born. et Flah. (Singh et al., 2011). Gutiérrez et al. (2008) isolated two abietane diterpenes from Microcoleous lacustris Desikachary and proved that they showed activity against bacteria Salmonella typhi (=S. enterica (ex Kauff. \& Edw.) Le Minor \& Popoff serovar Typhi), Staphylococcus aureus, S. epidermidis and Vibrio cholerae Pacini. Another species of cyanobacteria that produces antimicrobial peptides, including microviridine and cavaguchipeptin is Microcystis aeuroginosa Kütz. In addition, antibacterial activity was discovered from muscoride isolated from Nostoc muscorum C.Ag. ex Born. \& Flah., bastadine from Anabaena basta, microsporins from Nostoc commune, nostocycline A from Nostoc sp. and nostocin A from N. spongiaeforme C.Ag. ex Born. \& Flah. All these metabolites have antibacterial properties because they can destabilise bacterial cell walls (Głowacka et al., 2007).

\section{Cyanobacteria compounds with antifungal activity}

Many cyanobacteria also exhibit properties to inhibit fungal life processes. The methanol extract from Anabaena solitaria Kleb. has antifungal activity against Alternaria alternate (Fr.) Keissl., Botrytis cinereal Pers., and Colletotrichum gloeosporioides (Penz.) Penz. \& Sacc. Similarly is with cells from cyanobacteria Nostoc commune, which, in addition to the fungi mentioned above, also act against Fusarium oxysporium Schltdl., Phytophthora capsica Leon., Pythium ultimum Trow and Rhizopus stolonifer (Ehrenb.) Vuill. (Kim, 2006). The anti-fungal activity was also shown by ambigol A and B from Fischerella ambigua (Kütz. ex Born. \& Flah.) Gomont (Falch et al., 1995), fischerellin from F. muscicola Gomont (Srivastava et al., 1998) and tanicolide cryptophycins, and A-D majuskulamides from Lyngbya majuscula Harv. ex Gomont (Głowacka et al., 2007).

\section{Cyanobacteria compounds with anti-cancer activity}

It was found that some cyanometabolites have apoptotic properties. Such type of action have got, among others, dolastine, which was initially isolated from sea hares (family Aplysiidae), but later it was discovered that it is also produced by cyanobacteria (Costa et al., 2012). Thus, this compound can be used to suppress unnecessary and potentially harmful cells. Dolastine 10, a pentapeptide produced by Symploca sp., induces apoptosis of human lymphoblastic leukemia cells (Wall et al., 1999) and also has an inhibitory effect on lung cancer cells (Kalemkerian et al., 1999). Apatoxin D isolated from Lyngbya sp. has similar cytotoxic properties concerning lung cancer (Gutiérrez et al., 2008). Apratoxin A, extracted from L. majuscula Harv. ex Gomont cells, inhibits bone 
sarcoma cancer cells (Liu et al., 2009). Microcyclamide from Microcystis aeuroginosa has cytotoxic properties on murine P388 leukemia cells (Ishida et al., 2000). Calothrixin from cyanobacteria Calothrix sp. inhibits the growth of HeLa cervical cancer cells (Rickards et al., 1999). Majngulamide C from Lyngbya majuscula has inhibitory activity against lung cancer, large intestine cancer and glioblastoma cells (Vijayakumar, Menakha, 2015). Coibamide from Leptolyngbya sp. is a cyclic depsipeptide that causes cell cycle inhibition in the G1 phase for MDA-MB-435 breast cancer (Costa et al., 2014). Cryptophycin-1 from Nostoc linckia Born. ex Born. \& Flah. has a cytotoxic effect on cancer cells of the large intestine, prostate, solid tumors, colon cancer HT-29, Caco-2 and GC3, breast cancer MCF-7 and MDA-MB-231, HeLa cervical cancer, and also leukemia U937, CCRF-CEM and HL-60 (Shih, Teicher, 2001; Singh et al., 2011; Vijayakumar, Menakha, 2015). Nodularins and microcystin from cyanobacteria are toxic inhibitors of protein phosphatases PP1 and PP2A therefore, after appropriate chemical modification they can be used to produce analogues of potential drugs used to inhibit the processes leading to the formation of cancer (Łukomska et al., 2002). Costa et al. (2014) tested the anti-cancer activity of marine cyanobacterial strains. Five of them were the most interesting in terms of bioactive compounds: Leptolyngbya fragilis (Gomont) Anag. \& Kom., L. halophila (Hansgirg) Anag. \& Kom., L. mycoidea (Frémy) Anag., Nodosilinea nodulosa (Z.Li \& J.Brand) Perkerson \& Casamatta and Synechocystis salina Wislouch. It was also shown that two of them - L. fragilis and $S$. salina - are the most bioactive against cancer cells.

\section{Cyanobacteria compounds with antiprotozoal activity}

Tropical diseases such as malaria, cholera, leishmaniasis, African coma, schistosomiasis caused by protozoa are equally dangerous. According to WHO, over a billion people struggle with one or more of these diseases (Simmons et al., 2008). Cyanobacteria have been found to contain compounds that inhibit protozoa that cause these diseases. Viridamide A is a compound isolated from Oscillatoria nigrovirdis Thwaites ex Gomont that acts against Trypanosoma cruzi Chagas, Leishmania mexiana Garnham, and Plasmodium falciparum Schaudinn (Singh et al., 2011). Ambigol C from Fischerella ambigua (Kütz. ex Born. \& Flah.) Gomont acts against Trypanosoma rhodesiense and P. falciparum (Wright et al., 2005). In addition, a compound called nostocarboline extracted from Nostoc sp. also exhibits activity against protozoa such as Leishmania donovani Ross, P. falciparum, Trypanosoma brucei Plimmer \& Bradford and T. cruzi Chagas (Singh et al., 2011). 
Tab. 1. Examples of cyanobacterial with potential use in medicine and pharmaceutical industry

\begin{tabular}{|c|c|c|}
\hline Cyanobacteria & Effect & References \\
\hline Arthrospira platensis Gomont & $\begin{array}{l}\text { Antiviral activity (HIV type } 1 \text {, } \\
\text { Herpes simplex, Polio) }\end{array}$ & Głowacka et al. (2007) \\
\hline $\begin{array}{l}\text { Dichothrix baueriana Born. \& } \\
\text { Flah. }\end{array}$ & $\begin{array}{l}\text { Antiviral activity (Herpes sim- } \\
\text { plex type 2) }\end{array}$ & Larsen et al. (1994) \\
\hline Fischerella muscicola Gomont & Fungicides & Hagmann and Jüttner (1996) \\
\hline $\begin{array}{l}\text { Lyngbya lagerheimii (Gomont ex } \\
\text { Gomont) Anag. \& Kom. }\end{array}$ & Antiviral activity (HIV type 1 ) & Gustafson et al. (1989) \\
\hline Lyngbya sp. & Antitumor activity & Simmons et al. (2005) \\
\hline Nostoc sp. & $\begin{array}{l}\text { Cholinesterase inhibitor } \\
\text { (Alzheimer's disease) }\end{array}$ & Blom et al. (2006) \\
\hline Oscillatoria agardhii Gomont & Larvicidal activity & Harada et al. (2000) \\
\hline Phormidium tenue Gomont & Antiviral activity (HIV type 1 ) & Gustafson et al. (1989) \\
\hline Phormidium sp. & Fungicides (oral candidiasis) & Garima et al. (2013) \\
\hline Pseudoanabaena sp. & $\begin{array}{l}\text { Antibacterial activity (E. coli, } \\
\text { Salmonella sp.) }\end{array}$ & Głowacka et al. (2007) \\
\hline $\begin{array}{l}\text { Scytonema ocellatum Lyngb. ex } \\
\text { Born. \& Flah. }\end{array}$ & Fungicides & Patterson and Bolis (1995) \\
\hline $\begin{array}{l}\text { Symploca hydnoides Kütz. ex } \\
\text { Gomont }\end{array}$ & $\begin{array}{l}\text { Antiparasitic activity (malaria, } \\
\text { Chagas disease) }\end{array}$ & Linington et al. (2008) \\
\hline Westiellopsis sp. & $\begin{array}{l}\text { Larvicidal activity (malaria, } \\
\text { meningitis) }\end{array}$ & Rao et al. (1999) \\
\hline
\end{tabular}

Conclusions

Cyanobacteria have a wide range of occurrences and occupy many habitats, including oceanic areas, freshwater lakes, and even extreme habitats such as deserts, coastal rocks, glacial lakes or hot springs. In eutrophic and hypertrophic waters, cyanobacteria often dominate the phytoplankton in the summer period, creating a massive and harmful bloom. Some cyanobacteria produce toxins that can significantly affect human health. However, even though cyanobacteria contain toxic substances, there are species whose secreted organic compounds can be used as a potential source for commercial applications. The properties of cyanobacteria discussed in this work emphasize how these organisms can be potentially used by humans in many areas of their life. Cyanometabolites can serve as drugs for incurable diseases such as cancer or other diseases caused by bacteria, viruses, fungi or protozoa. However, the composition and functional role of many cyanometabolites remain unknown, therefore, the issue of commercial application of cyanobacteria and their cyanometabolites require more attention and investigation.

This study was supported by BMN grants, Poland, no. 538-G245-B116-18.

Acknowledgements This study was supported by BMN grants, Poland, no. 538-G245-B116-18.

Conflict of interest

The author declares no conflict of interest related to this article. 


\section{References}

AlgaeBase https://www.algaebase.org/. 1996-2019 M.D. Guiry.

Almeida, J., Freitas, M., Cruz, S., Leão, P., Vasconcelos, V., Cunha, I. (2015). Acetylcholinesterase in biofouling species: characterization and mode of action of cyanobacteria-derived antifouling agents. Toxins, 7, 2739-2756. DOI: 10.3390/toxins7082739

Berry, J.P., Gantar, M., Perez, M.H., Berry, G., Noriega, F.G. (2008). Cyanobacterial toxins as allelochemicals with potential applications as algaecides, herbicides and insecticides. Marine Drugs, 15, 117-146. DOI: $10.3390 / \mathrm{md} 20080007$

Blom, J.F., Brütsch, T., Barbaras, D., Bethuel, Y., Locher, H.H., Hubschwerlen, C., Gademann, K. (2006). Potent algicides based on the cyanobacterial alkaloid nostocarboline. Organic Letters, 8(4), 737-740. DOI: $10.1021 / \mathrm{ol} 052968 \mathrm{~b}$

Bokesch, H.R., O’Keefe, B.R., McKee, T.C., Pannell, L.K., Patterson, G.M., Gardella, R.S., Boyd, M.R. (2003). A potent novel anti-HIV protein from the cultured cyanobacterium Scytonema varium. Biochemistry, 42(9), 2578-2584. DOI: 10.1021/bi0205698

Burja, A.M., Banaigs, B., Abou-Mansour, E., Burgess, J.G., Wright, P.C. (2001). Marine cyanobacteria - a prolific source of natural products. Tetrahedron, 57(46), 9347-9377. DOI: 10.1016/S00404020(01)00931-0

Costa, M., Costa-Rodrigues, J., Fernandes, M.H., Barros, P., Vasconcelos, V., Martins, R. (2012). Marine cyanobacteria compounds with anticancer properties: A review on the implication of apoptosis. $\mathrm{Ma}$ rine Drugs, 10(10), 2181-2207. DOI: 10.3390/md10102181

Costa, M., Garcia, M., Costa-Rodrigues, J., Costa, M.S., Ribeiro, M.J., Fernandes, M.H., Martins, R. (2014). Exploring bioactive properties of marine cyanobacteria isolated from the Portuguese Coast: High potential as a source of anticancer compounds. Marine Drugs, 12, 98-114. DOI: 10.3390/ md12010098

El-Baky, H.H.A. (2003). Over production of phycocyanin pigment in blue green alga Spirulina sp. and it's inhibitory effect on growth of Ehrlich ascites carcinoma cells. Journal of Medical Science, 3(4), 314-324. DOI: 10.3923/jms.2003.314.324

Falch, B.S., König, G.M., Wright, A.D., Sticher, O., Angerhofer, C.K., Pezzuto, J.M., Bachmann, H. (1995). Biological activities of cyanobacteria: evaluation of extracts and pure compounds. Planta Medica, 61(04), 321-328. DOI: 10.1055/s-2006-958092

Garima, A.C., Goyal, P., Kaushik, P. (2013). Antibacterial and anticandidal screening of extracellular and intracellular extracts of Phormedium, a Cyanobacterium. International Journal of Chemical and Life Sciences, 2, 1107-1111.

Głowacka, J., Waleron, M., Szefel-Markowska, M., Łojkowska, E., Waleron, K. (2007). Cyanobacteria source of biologically active compounds. Biotechnologia, 4(79), 95-112. [In Polish]

Gupta, V., Ratha, S.K., Sood, A., Chaudhary, V., Prasanna, R. (2013). New insights into the biodiversity and applications of cyanobacteria (blue-green algae) - prospects and challenges. Algal Research, 2(2), 79-97. DOI: 10.1016/j.algal.2013.01.006

Gustafson, K.R., Cardellina, J.H., Fuller, R.W., Weislow, O.S., Kiser, R.F., Snader, K.M., Patterson, G.M.L., Boyd, M.R. (1989). AIDS-antiviral sulfolipids from cyanobacteria (blue-green algae). JNCI: Journal of the National Cancer Institute, 81(16), 1254-1258.

Gutiérrez, M., Suyama, T.L., Engene, N., Wingerd, J.S., Matainaho, T., Gerwick, W.H. (2008). Apratoxin D, a potent cytotoxic cyclodepsipeptide from Papua New Guinea collections of the marine cyanobacteria Lyngbya majuscula and Lyngbya sordida. Journal of Natural Products, 71(6), 1099-1103. DOI: 10.1021/np800121a 
Hagmann, L., Jüttner, F. (1996). Fischerellin A, a novel photosystem-II-inhibiting allelochemical of the cyanobacterium Fischerella muscicola with antifungal and herbicidal activity. Tetrahedron Letters, 37(36), 6539-6542. DOI: 10.1016/0040-4039(96)01445-1

Harada, K.I., Suomalainen, M., Uchida, H., Masui, H., Ohmura, K., Kiviranta, J., Niku-Paavola, M.L., Ikemoto, T. (2000). Insecticidal compounds against mosquito larvae from Oscillatoria agardhii strain 27. Environmental Toxicology: An International Journal, 15(2), 114-119. DOI: 10.1002/(SICI)15227278(2000)15:23.0.CO;2-P

Imhoff, J.F., Labes, A., Wiese, J. (2011). Bio-mining the microbial treasures of the ocean: new natural products. Biotechnology Advances, 29, 468-482. DOI: 10.1016/j.biotechadv.2011.03.001

Ishida, K., Nakagawa, H., Murakami, M. (2000). Microcyclamide, a cytotoxic cyclic hexapeptide from the cyanobacterium Microcystis aeruginosa. Journal of Natural Products, 63(9), 1315-1317. DOI: $10.1021 / \mathrm{np} 000159 \mathrm{p}$

Ishimi, Y., Sugiyama, F., Ezaki, J., Fujioka, M., Wu, J. (2006). Effects of Spirulina, a blue-green alga, on bone metabolism in ovariectomized rats and hindlimb-unloaded mice. Bioscience, Biotechnology, and Biochemistry, 70(2), 363-368. DOI: 10.1271/bbb.70.363

Kalemkerian, G.P., Ou, X., Adil, M.R., Rosati, R., Khoulani, M.M., Madan, S.K., Pettit, G.R. (1999). Activity of dolastatin 10 against small-cell lung cancer in vitro and in vivo: induction of apoptosis and bcl-2 modification. Cancer Chemotherapy and Pharmacology, 43(6), 507-515. DOI: 10.1007/ s002800050931

Kim, J.D. (2006). Screening of cyanobacteria (blue-green algae) from rice paddy soil for antifungal activity against plant pathogenic fungi. Mycobiology, 34(3), 138-142. DOI: 10.4489/MYCO.2006.34.3.138

Klasik, S., Zych, M., Kaczmarczyk-Sedlak, I. (2010). Cyanobacteria (Cyanophyta)-classification, structure of the cell and significance; Spirulina platensis and her therapeutic significance for the human's body. Medycyna Rodzinna, 4, 120-123.

Kreitlow, S., Mundt, S., Lindequist, U. (1999). Cyanobacteria - a potential source of new biologically active substances. Journal of Biotechnology, 70(1-3), 61-63. DOI: 10.1016/S0168-1656(99)00058-9

Lam, K.S. (2007). New aspects of natural products in drug discovery. Trends in Microbiology, 15(6), 279289. DOI: $10.1016 /$ j.tim.2007.04.001

Larsen, L.K., Moore, R.E., Patterson, G.M. (1994). $\beta$-Carbolines from the blue-green alga Dichothrix baueriana. Journal of Natural Products, 57(3), 419-421. DOI: 10.1021/np50105a018

Lau, A.F., Siedlecki, J., Anleitner, J., Patterson, G.M., Caplan, F.R., Moore, R.E. (1993). Inhibition of reverse transcriptase activity by extracts of cultured blue-green algae (Cyanophyta). Planta Medica, 59(2), 148-151. DOI: 10.1055/s-2006-959631

Leão, P.N., Engene, N., Antunes, A., Gerwick, W.H., Vasconcelos, V. (2012). The chemical ecology of cyanobacteria. Natural Product Reports, 29, 372-391. DOI: 10.1039/c2np00075j

Linington, R.G., Edwards, D.J., Shuman, C.F., McPhail, K.L., Matainaho, T., Gerwick, W.H. (2008). Symplocamide A, a potent cytotoxin and chymotrypsin inhibitor from the marine cyanobacterium Symploca sp. Journal of Natural Products, 71(1), 22-27. DOI: 10.1021/np070280x

Liu, Y., Law, B.K., Luesch, H. (2009). Apratoxin a reversibly inhibits the secretory pathway by preventing cotranslational translocation. Molecular Pharmacology, 76(1), 91-104. DOI: 10.1124/mol.109.056085

Łukomska, J., Kasprzykowski, F., Łankiewicz, L., Grzonka, Z. (2002). Peptide toxins from cyanobacteria. Wiadomości Chemiczne, 56(1-2), 57-82. [In Polish]

Mazur-Marzec, H., Błaszczyk, A., Felczykowska, A., Hohlfeld, N., Kobos, J., Toruńska-Sitarz, A., Devi, P., Montalvão, S., D’souza, L., Tammela, P., Mikosik, A., Bloch, S., Nejman-Faleńczyk, B., Węgrzyn, G. (2015). Baltic cyanobacteria-a source of biologically active compounds. European Journal of Phycology 50, 343-360. DOI: 10.1080/09670262.2015.1062563 
Nuhu, A.A. (2013). Spirulina (Arthrospira): An important source of nutritional and medicinal compounds. Journal of Marine Biology, ID 325636. DOI: 10.1155/2013/325636

Oufdou, K., Mezrioui, N., Oudra, B., Loudiki, M., Barakate, M., Sbiyyaa, B. (2001). Bioactive compounds from Pseudanabaena species (Cyanobacteria). Microbios, 106, 21-29.

Patterson, G.M.L., Bolis, C.M. (1995). Regulation of scytophycin accumulation in cultures of Scytonema ocellatum. II. Nutrient requirements. Applied Microbiology and Biotechnology, 43(4), 692-700. DOI: 10.1007/BF00164775

Rao, D.R., Thangavel, C., Kabilan, L., Suguna, S., Mani, T.R., Shanmugasundaram, S. (1999). Larvicidal properties of the cyanobacterium Westiellopsis sp. (blue-green algae) against mosquito vectors. Transactions of the Royal Society of Tropical Medicine and Hygiene, 93(3), 232-232. DOI: 10.1016/ S0035-9203(99)90002-0

Rickards, R.W., Rothschild, J.M., Willis, A.C., de Chazal, N.M., Kirk, J., Kirk, K., Smith, G.D. (1999). Calothrixins A and B, novel pentacyclic metabolites from Calothrix cyanobacteria with potent activity against malaria parasites and human cancer cells. Tetrahedron, 55(47), 13513-13520. DOI: 10.1016/S0040-4020(99)00833-9

Rubio, B.K., Parrish, S.M., Yoshida, W., Schupp, P.J., Schils, T., Williams, P.G. (2010). Depsipeptides from a Guamanian marine cyanobacterium, Lyngbya bouillonii, with selective inhibition of serine proteases. Tetrahedron Letters, 51(51), 6718-6721.

Sheih, I.C., Fang, T.J., Wu, T.K., Lin, P.H. (2009). Anticancer and antioxidant activities of the peptide fraction from algae protein waste. Journal of Agricultural and Food Chemistry, 58(2), 1202-1207. DOI: $10.1021 /$ jf903089m

Shih, C., Teicher, B.A. (2001). Cryptophycins: a novel class of potent antimitotic antitumor depsipeptides. Current Pharmaceutical Design, 7(13), 1259-1276. DOI: 10.2174/1381612013397474

Simmons, T.L., Andrianasolo, E., McPhail, K., Flatt, P., Gerwick, W.H. (2005). Marine natural products as anticancer drugs. Molecular Cancer Therapeutics, 4(2), 333-342.

Simmons, T.L., Engene, N., Ureña, L.D., Romero, L.I., Ortega-Barría, E., Gerwick, L., Gerwick, W.H. (2008). Viridamides A and B, lipodepsipeptides with antiprotozoal activity from the marine cyanobacterium Oscillatoria nigro-viridis. Journal of Natural Products, 71(9), 1544-1550. DOI: 10.1021/ np800110e

Singh, R.K., Tiwari, S.P., Rai, A.K., Mohapatra, T.M. (2011). Cyanobacteria: an emerging source for drug discovery. The Journal of Antibiotics, 64(6), 401. DOI: 10.1038/ja.2011.21

Srivastava, A., Jüttner, F., Strasser, R.J. (1998). Action of the allelochemical, fischerellin A, on photosystem II. Biochimica et Biophysica Acta (BBA)-Bioenergetics, 1364(3), 326-336. DOI: 10.1016/S00052728(98)00014-0

Vijayakumar, S., Menakha, M. (2015). Pharmaceutical applications of cyanobacteria - A review. Journal of Acute Medicine, 5(1), 15-23. DOI: 10.1016/j.jacme.2015.02.004

Wall, N.R., Mohammad, R.M., Al-Katib, A.M. (1999). Bax: Bcl-2 ratio modulation by bryostatin 1 and novel antitubulin agents is important for susceptibility to drug induced apoptosis in the human early pre-B acute lymphoblastic leukemia cell line, Reh. Leukemia Research, 23(10), 881-888. DOI: 10.1016/s0145-2126(99)00108-3

Wright, A.D., Papendorf, O., König, G.M. (2005). Ambigol C and 2, 4-Dichlorobenzoic Acid, Natural Products Produced by the Terrestrial Cyanobacterium Fischerella ambigua. Journal of Natural Products, 68(3), 459-461. DOI: 10.1021/np049640w

Yasuhara-Bell, J., Lu, Y. (2010). Marine compounds and their antiviral activities. Antiviral Research, 86(3), 231-240. DOI: 10.1016/j.antiviral.2010.03.009

Zainuddin, E., Mundt, S., Wegner, U., Mentel, R. (2002). Cyanobacteria a potential source of antiviral 
substances against influenza virus. Medical Microbiology and Immunology, 191(3-4), 181-182. DOI: $10.1007 / \mathrm{s} 00430-002-0142-1$

\section{Cyjanobakterie i cyjanometabolity stosowane w przemyśle farmaceutycznym oraz medycznym \\ Streszczenie}

Związki bioaktywne sinic wykazują różnorodne właściwości, które potencjalnie mogą być wykorzystane $\mathrm{w}$ wielu sektorach przemysłu. W artykule tym szczególny nacisk położono na wykorzystanie sinic i ich cyjanometabolitów, zarówno w przemyśle farmaceutycznym, jak i medycznym. Scharakteryzowano związki wyizolowane ze szczepów sinic, które można stosować do wytwarzania leków o działaniu przeciwwirusowym, przeciwgrzybiczym, przeciwnowotworowym, przeciwdrobnoustrojowym oraz przeciwbakteryjnym. Pokazano również pozytywne aspekty hodowli sinic i możliwości ich komercyjnego wykorzystania.

Key words: applications, blue-green algae, cyanobacteria, cyanometabolites, industry

Received: [2019.11.05]

Accepted: [2019.12.05] 